\title{
Optimization of UPLC Method for Simultaneous Determination of Rosuvastatin and Rosuvastatin Degradation Products
}

\author{
Jure Zakrajšek, ${ }^{1, \star}$ Katarina Bevc-Černilec, ${ }^{1}$ Simona Bohanec ${ }^{1}$ and Uroš Urleb ${ }^{2}$ \\ ${ }^{1}$ Lek Pharmaceuticals d.d., Development Center Slovenia, Verovškova 57, 1526 Ljubljana, Slovenia \\ ${ }^{2}$ Biologics Technical development and Manufacturing, Novartis, Verovškova 57, 1526 Ljubljana, Slovenia \\ * Corresponding author: E-mail: jure.zakrajsek@sandoz.com; \\ Tel.: +386158026 30, Fax.: +38615681393
}

Received: 23-06-2017

\begin{abstract}
An ultra-performance liquid chromatographic method for simultaneous determination of rosuvastatin and rosuvastatin degradation products was developed and optimized by using fractional factorial experimental design. Optimized method is capable to accurately determine all potential degradation products of rosuvastatin. During the optimization the effect of four chosen chromatographic factors was evaluated. The analytical method operational design region was modeled using Umetrics MODDE software and optimal chromatographic conditions were predicted. The results of the model show that the most important factors to reach good separation between the peaks of rosuvastatin impurities are the $\mathrm{pH}$ of buffer solution and the amount of ACN and THF in the mobile phase. The final optimized method using QbD approach was validated for linearity, accuracy and precision for determination of rosuvastatin and rosuvastatin degradation products in rosuvastatin pharmaceutical dosage forms. Limit of detection and quantification were determined for two known specified impurities. The use of experimental designs enabled us to obtain the maximum amount of information about the analytical method design region. Optimization of the method was done without additional experiments, only weighing the responses and rebuilding the statistical model. This approach is very cost-effective when evaluating a variety of different factors and their interactions.
\end{abstract}

Keywords: Fractional factorial design; experimental design; UPLC method optimization; rosuvastatin

\section{Introduction}

Rosuvastatin belongs to the statin class of pharmaceutical substances that are used for lowering of low-density lipoprotein cholesterol (LDL-C).

Rosuvastatin is mainly administered as a calcium salt of the active hydroxy acid in tablets with $2.5,5,10,20$ or $40 \mathrm{mg}$ of rosuvastatin (RSV). Rosuvastatin substance is chemically not stable and degrades into many known and unknown degradation products under different stress conditions (thermal, oxidative, and/or photolytic) ${ }^{1}$. The structural formulas of rosuvastatin and its known impurities are shown in Figure 1.

It is a white amorphous powder only sparingly soluble in water and slightly soluble in ethanol. It contains a polar methane sulphonamide group that interacts with the HMG-CoA reductase. ${ }^{2,3}$
Efforts for applying concepts of quality by design $(\mathrm{QbD})$ principles to analytical method development have increased in recent years in order to achieve more accurate, robust and rigged analytical methods which are used for better control strategy of production processes. ${ }^{4-6}$ While quality by design principles are well known and adopted for the development of pharmaceutical products, ${ }^{7,8}$ $\mathrm{QbD}$ concept has not yet been fully adopted for analytical method development and optimization.

Different experimental designs are used for the evaluation of the effects of different factors and their interactions for process optimization and design space modeling. Compatibility studies between the drug substance and other excipients performed by experimental designs are also described in literature. ${ }^{9}$ Maximum amount of obtained information with the smallest possible number of experiments was achieved by this approach. ${ }^{9}$ Effect of dif- 
<smiles>CC(C)c1nc(N(C)S(C)(=O)=O)nc(-c2ccc(F)cc2)c1/C=C/[C@@H](O)C[C@H](O)CC(=O)O</smiles>

Rosuvastatin

(3R,5S,E)-7-(4-(4-fluorophenyl)-6-isopropyl2-( $N$-methylmethylsulfonamido)pyrimidin-5yl)-3,5-dihydroxyhept-6-enoic acid<smiles>CC(C)c1nc(N(C)S(C)(=O)=O)nc(-c2ccc(F)cc2)c1/C=C/C(=O)C[C@@H](O)CC(=O)O</smiles>

Rosuvastatin oxo impurity

(R,E)-7-(4-(4-fluorophenyl)-6-isopropyl-2( $N$-methylmethylsulfonamido)pyrimidin-5yl)-3-hydroxy-5-oxohept-6-enoic acid<smiles>CC(C)c1nc(N(C)S(C)(=O)=O)nc(-c2ccc(F)cc2)c1/C=C/[C@H](O)C[C@H](O)CC(=O)O</smiles>

Rosuvastatin diastereoisomer

(3S,5S,E)-7-(4-(4-fluorophenyl)-6-isopropyl2-( $N$-methylmethylsulfonamido)pyrimidin-5yl)-3,5-dihydroxyhept-6-enoic acid<smiles>CC(C)c1nc(N(C)S(C)(=O)=O)nc(-c2ccc(F)cc2)c1/C=C/[C@H]1C[C@@H](O)CC(=O)O1</smiles>

Rosuvastatin lactone impurity $N$-(4-(4-fluorophenyl)-5-( $(E)-2-((2 S, 4 R)-4$ hydroxy-6-oxotetrahydro- $2 H$-pyran-2yl)vinyl)-6-isopropylpyrimidin-2-yl)- $N$ methylmethanesulfonamide<smiles>CC(C)c1nc(N(C)S(C)(=O)=O)nc(-c2ccc(F)cc2)c1/C=C/[C@@H](O)C/C=C/C(=O)O</smiles>

Rosuvastatin dehydro impurity

(S,2E,6E)-7-(4-(4-fluorophenyl)-6-isopropyl-2-

( $N$-methylmethylsulfonamido)pyrimidin-5-yl)-

5-hydroxyhepta-2,6-dienoic acid

Figure 1. Structural formula of rosuvastatin (RSV) and its known impurities (RSV diastereoisomer, RSV oxo, RSV lactone, RSV dehydro).

ferent process and formulation parameters on chemical stability of the final drug product was also studied by using fractional factorial designs. ${ }^{10}$

The same principles of $\mathrm{QbD}$ can be applied to analytical method development/optimization in order to develop more robust analytical methods and determine the analytical method operation design region. ${ }^{11,12}$

The proposed concept is designed around the analytical target profile (ATP), which predefines the requirements for the analytical method. During the development phase of the analytical method one must show that the analytical method confirms to the criteria set in the ATP. ${ }^{13}$

Use of experimental designs (DoE) in order to assess the multidimensional combination and interactions of factors that could affect the measurements is suggested. ${ }^{14}$
Different experimental designs can be used and are described in the literature to evaluate the effect of different chromatographic parameters such as a buffer $\mathrm{pH}$ value, column temperature, percentage of organic modifier in the mobile phase and others. ${ }^{15-17}$ The same concepts can be applied not only to chromatographic analytical methods, but also to other analytical techniques such as Karl Fisher titration for water content determination. ${ }^{18}$

To assure the quality of pharmaceutical dosage forms containing rosuvastatin calcium as active ingredient, the assay of rosuvastatin and its degradation products needs to be controlled by a validated analytical method. Various analytical methods have been reported in the literature for determination of rosuvastatin in different pharmaceutical 
dosage forms including combinational products. These include HPTLC, ${ }^{19}$ HPLC with ultraviolet detection ${ }^{20-24}$ and UPLC with ultraviolet detection. ${ }^{25}$

Different HPLC methods with ultraviolet detection have been published for the determination of rosuvastatin degradation products. ${ }^{25-27}$ Several methods have also been published for the determination of rosuvastatin in biological fluids using RP-HPLC/UV detection ${ }^{28}$ or LC/MS. ${ }^{29}$

The objective of this work was to develop a new analytical method that could simultaneously be used for the determination of rosuvastatin and rosuvastatin degradation products in rosuvastatin pharmaceutical dosage forms. The method has to be stability indicating ${ }^{30}$ and capable to detect all changes in product quality during stability testing at various stability conditions according to regulatory requirements (accelerated, long-term or stress stability). ${ }^{31}$ Simultaneous determination of rosuvastatin and its degradation products with one analytical method is a great benefit regarding time and resources, taking into account the number of samples that need to be analyzed during the stability studies for regulatory purposes. In addition the method should be accurate, precise and linear with acceptable limit of detection and qualification for all specified impurities (RSV oxo and RSV lactone). ${ }^{32}$ The development of the method was done by using QbD principles. The optimization step of the development was performed using experimental designs and analytical method operational design region modeling. A degraded sample from two different stress conditions (photolytic and acidic conditions) was used for the final optimization step.

\section{Experimental}

\section{1. Chemicals and Reagents}

Anhydrous acetic acid $\left(\mathrm{CH}_{3} \mathrm{COOH}\right)$, ammonium acetate $\left(\mathrm{CH}_{3} \mathrm{COONH}_{4}\right)$, tetrahydrofuran (THF) purchased from Merck KGaA (Darmstadt, Germany), acetonitrile $\left(\mathrm{CH}_{3} \mathrm{CN}-\mathrm{ACN}\right)$ purchased from J.T. Baker (Avantor Performance Materials, Center Valley, PA) were used for preparation of mobile phases and solvents. Acetonitrile and tetrahydrofuran were of HPLC grade, all other chemicals were of analytical grade.

Milli-Q water purification system (Millipore Corp., Bedford, MA) was used to obtain highly purified water used for all aqueous solutions.

In-house rosuvastatin tert-octylammonium working standard, rosuvastatin oxo tert-octylammonium and rosuvastatin lactone identification standards were used for preparation of standard solutions used for validation and analysis of drug product.

Stock buffer solutions with different $\mathrm{pH}$ were prepared by weighing $1.54 \mathrm{~g}$ of ammonium acetate and dissolving in $1000 \mathrm{~mL}$ of highly purified water. $\mathrm{pH}$ of buffer solution was adjusted to defined $\mathrm{pH}$ value using anhydrous acetic acid.

Mixture of stock buffer solution : acetonitrile $=600$ : $400(\mathrm{v} / \mathrm{v})$ was used as solvent for standard and sample preparation.

\section{2. Equipment}

Experiments were performed on a Waters Acquity UPLC separation module, equipped with a quaternary gradient pump, temperature controlled column heater, sampler manager and dual wavelength UV detector (Waters Corporation, Milford, MA). Instrument control was performed using Empower 3 Software for chromatography (Waters Corporation, Milford, MA). Same software was used for data acquisition and processing of results.

Waters Acquity UPLC HSS C18 analytical chromatographic column $(100 \times 2.1 \mathrm{~mm}, 1.8 \mu \mathrm{m})$ provided by Waters Corporation (Milford, MA) was used for all optimization experiments.

$\mathrm{pH}$ measurements and adjustments were performed with Mettler-Toledo SevenMulti pH meter using a Mettler-Toledo InLab Expert Pro pH electrode (Mettler-Toledo LLC, Columbus, OH).

Mobile phases were vacuum filtered prior the use through Omnipore ${ }^{\mathrm{TM}} 0.1 \mu \mathrm{m}$ JV filter, purchased from Millipore (Billerica, MA).

Suntest chamber Atlas SUNTEST XLS+ (Atlas, Mount Prospect, IL) was used to expose sample solutions to artificial sunlight according to ICH guideline for Photostability. ${ }^{33}$

Samples and standard solutions were filtered through Millipore Millex-GV Hydrophilic PVDF $0.22 \mu \mathrm{m}$ disk filters, purchased from Millipore (Billerica, MA), before the analysis was performed using UPLC method.

\section{3. Analytical Method}

Fast gradient UPLC method was developed for simultaneous determination of rosuvastatin and its degradation products in rosuvastatin formulations with a single injection of the sample and UV detection at two different wavelengths. The initial chromatographic conditions are summarized in Table 1.

The initial method was optimized due to the insufficient resolution between rosuvastatin peak (RSV) and RSV diastereoisomer as presented in the chromatogram of peak identification solutions shown in Figure 2.

We have optimized the initial chromatographic parameters using a fractional factorial experimental design. The goal of the optimization was to achieve better resolution between rosuvastatin peak and rosuvastatin diastereoisomer and not worsen the resolution between other peaks of degradation products within the chromatogram. 
Table 1. Chromatographic conditions of the initial UPLC method for assay determination of rosuvastatin.

Mobile phase A

Mobile phase B

Column

Column temperature

Flow rate

Detection wavelength

Injection volume

\begin{tabular}{|c|c|c|c|}
\hline \multirow{5}{*}{ Gradient parameters } & Time & $\% \mathrm{~A}$ & $\% \mathrm{~B}$ \\
\hline & 0 & 88 & 12 \\
\hline & 8.5 & 88 & 12 \\
\hline & 19.5 & 30 & 70 \\
\hline & 20 & 88 & 12 \\
\hline
\end{tabular}

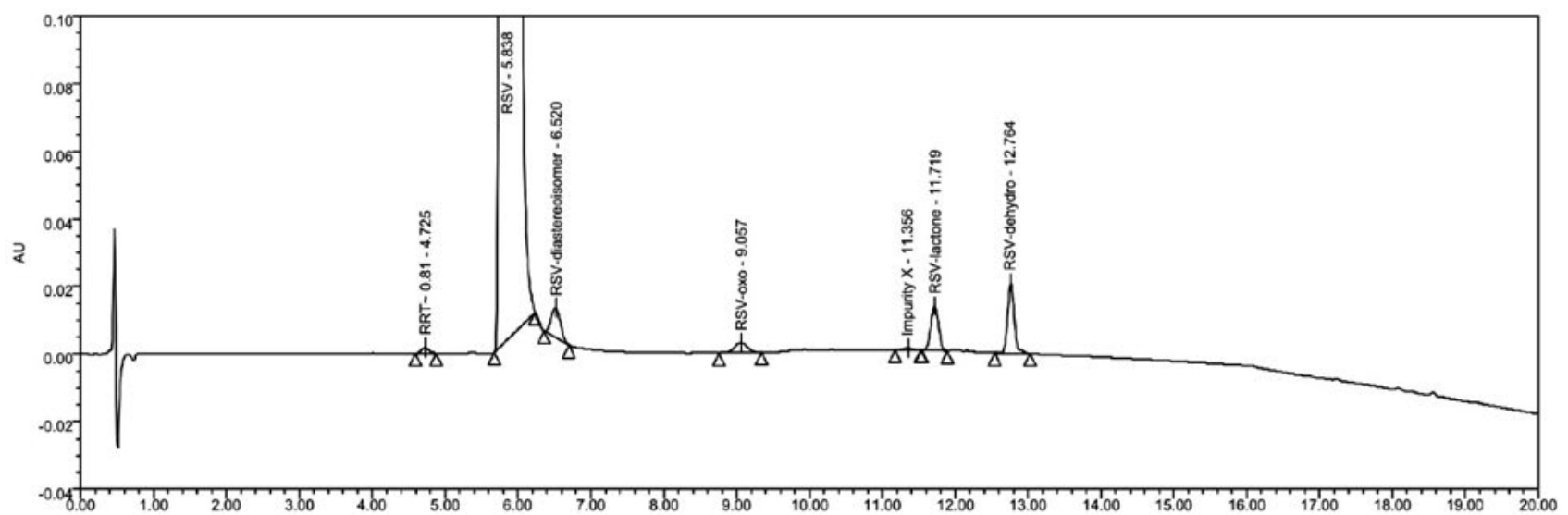

Figure 2. Chromatogram of peak identification solution analyzed with initial chromatographic conditions.

\section{4. Standard Solutions}

Stock standard solution of rosuvastatin working standard $(0.5 \mathrm{mg} / \mathrm{mL})$ was prepared by dissolving appropriate amount of rosuvastatin working standard in solvent.

Working concentrations of rosuvastatin standard solutions were achieved by diluting the stock standard solution with solvent to concentration $2.5 \mu \mathrm{g} / \mathrm{mL}$ (used for the quantitation of degradation products) and concentration $0.25 \mu \mathrm{g} / \mathrm{mL}$ (used for signal-to-noise determination).

Stock standard solution was used for assay determination of rosuvastatin.

Different concentrations of standard solution used in the validation were achieved by diluting the stock standard solution with solvent.

Stock solutions of rosuvastatin oxo $(100 \mu \mathrm{g} / \mathrm{mL})$ and rosuvastatin lactone $(100 \mu \mathrm{g} / \mathrm{mL})$ standards were prepared by dissolving appropriate amount of rosuvastatin oxo or rosuvastatin lactone standard in solvent. Stock solutions were used to prepare spiked samples at appropriate concentration levels used in the validation study.
All standard solutions were filtered through Millipore Millex-GV Hydrophilic PVDF $0.22 \mu \mathrm{m}$ filter into vials.

\section{5. Analysis of Samples}

Samples were prepared by dissolving 10 rosuvastatin tablets in appropriate volume of solvent to acquire a concentration $0.5 \mathrm{mg} / \mathrm{mL}$ of rosuvastatin. In addition, ultrasonic bath was used to achieve complete disintegration of the tablets.

All sample solutions were filtered through Millipore Millex-GV Hydrophilic PVDF $0.22 \mu \mathrm{m}$ filter into vials and analyzed with the analytical method.

To evaluate a resolution between unknown impurity X and RSV lactone impurity a degraded sample of rosuvastatin tablets was prepared. Two stock sample solutions were exposed to different degradation conditions. One sample solution was exposed to artificial sunlight under which the unknown impurity $\mathrm{X}$ was formed. Hydrochloric acid was added to the second sample solution, as rosuvastatin lactone impurity is known to form under acidic conditions. Both samples were mixed in $1: 1(\mathrm{v} / \mathrm{v})$ 
ratio to obtain a sample that was used for optimization purposes.

\section{Results and Discussion}

\section{1. Chromatographic Condition Optimization}

Screening of the influence of four chromatographic factors on different chromatographic responses was performed as the initial step of analytical method optimization. A randomized fractional factorial experimental design $\left(2^{4-1}\right)$ of resolution IV with central point was used. Buffer $\mathrm{pH}$, amount of acetonitrile in mobile phase $\mathrm{A}$, the amount of organic modifier tetrahydrofuran in mobile phase A and column temperature were selected as factors

Table 2. Factors and corresponding levels for $2^{4-1}$ fractional factorial design used for screening analysis.

\begin{tabular}{lccc}
\hline Factor name & Abbr. & Settings & Initial \\
\hline (f1) Buffer pH & $\mathrm{pH}$ & 3.3 to 3.9 & 3.6 \\
(f2) Amount of THF & $\mathrm{THF}$ & 30 to $50 \mathrm{~mL}$ & $40 \mathrm{~mL}$ \\
(f3) Amount of ACN & $\mathrm{ACN}$ & 175 to $225 \mathrm{~mL}^{*}$ & $200 \mathrm{~mL}$ \\
(f4) Column temperature & Temp & 25 to $35^{\circ} \mathrm{C}$ & $30^{\circ} \mathrm{C}$ \\
\hline
\end{tabular}

${ }^{*}$ Change in ACN volume was compensated with defined buffer solution volume so that the total volume of buffer solution and ACN was not changed. of interest, and were used to generate the fractional factorial experimental design. All factors and their corresponding levels are shown in Table 2.

Fractional factorial experimental design was generated using Umetrics MODDE 11.0 software.

Eleven experiments presented in Table 4 were carried out according to the generated experimental design. Three central point experiments (experiment N9, N10 and N11) were also included for the determination of experimental error. All experiments were carried out in a randomized order (run order) in order to eliminate any systematic errors.

Six chromatographic responses presented in Table 3 were selected and measured for all performed experiments: resolution between rosuvastatin (RSV) peak and RSV diastereoisomer (Res 1), resolution between impurity X peak and RSV lactone peak (Res 2), resolution between RSV lactone peak and RSV dehydro impurity peak (Res 3$)$, number of theoretical plates of rosuvastatin peak $(\mathrm{N})$, symmetry factor for rosuvastatin peak $(\mathrm{T})$ and retention time or rosuvastatin peak (Rt).

The results of experiments are presented in Table 4.

All obtained and collected response measurements were processed with Umetrics MODDE software. Partial least squares (PLS) multivariate method of simultaneously estimating the models for all the responses was used for fitting and optimizing the statistical model. PLS method

Table 3. Responses and used suitability criteria for method optimization and sweet spot analysis.

\begin{tabular}{lcccc}
\hline \multirow{2}{*}{ Response name } & \multirow{2}{*}{ Abbr. } & \multicolumn{3}{c}{ Suitability criteria } \\
& & Min & Target & Max \\
\hline Resolution RSV, RSV diastereoisomer & Res 1 & 2.5 & 3.0 & - \\
Resolution impurity X, RSV lactone & Res 2 & 1.5 & 2.0 & - \\
Resolution RSV lactone, RSV dehydro & Res 3 & 6.0 & 6.5 & - \\
Number of theoretical plates of RSV peak & N & 7000 & 7500 & - \\
Symmetry factor for RSV peak & T & 0.8 & 1.0 & 1.6 \\
Retention time or RSV peak & Rt & - & 6.0 & 6.5 \\
\hline
\end{tabular}

Table 4. Randomized $2^{4-1}$ fractional factorial design and results of observed responses.

\begin{tabular}{|c|c|c|c|c|c|c|c|c|c|c|c|}
\hline \multirow{2}{*}{$\begin{array}{l}\operatorname{Exp} \\
\text { No }\end{array}$} & \multirow{2}{*}{$\begin{array}{l}\text { Run } \\
\text { Order }\end{array}$} & \multicolumn{4}{|c|}{ Factors } & \multicolumn{6}{|c|}{ Responses } \\
\hline & & f1 & f2 & f3 & f4 & Res 1 & Res 2 & Res 3 & $\mathbf{N}$ & $\mathbf{T}$ & Rt \\
\hline N1 & 1 & - & - & - & - & 3.39 & 1.39 & 5.48 & 7976 & 1.59 & 9.432 \\
\hline $\mathrm{N} 2$ & 11 & + & - & - & + & 2.98 & 1.26 & 3.30 & 8379 & 1.66 & 8.907 \\
\hline N3 & 3 & - & + & - & + & 2.55 & n.a. & 7.74 & 6930 & 1.51 & 5.493 \\
\hline $\mathrm{N} 4$ & 4 & + & + & - & - & 2.66 & 1.69 & 5.09 & 7401 & 1.53 & 6.951 \\
\hline N5 & 8 & - & - & + & + & 2.30 & 1.68 & 6.19 & 6361 & 1.45 & 4.368 \\
\hline N6 & 2 & + & - & + & + & 2.07 & 1.57 & 3.25 & 6537 & 1.45 & 4.383 \\
\hline N7 & 7 & - & + & + & - & 2.22 & 1.64 & 6.63 & 5643 & 1.37 & 3.87 \\
\hline N8 & 10 & + & + & + & - & 2.07 & 1.83 & 4.86 & 6138 & 1.37 & 4.037 \\
\hline N9 & 9 & 0 & 0 & 0 & 0 & 2.63 & 1.54 & 5.78 & 7526 & 1.51 & 5.846 \\
\hline N10 & 5 & 0 & 0 & 0 & 0 & 2.64 & 1.57 & 5.77 & 7186 & 1.54 & 5.838 \\
\hline N11 & 6 & 0 & 0 & 0 & 0 & 2.63 & 1.60 & 5.78 & 7217 & 1.54 & 5.844 \\
\hline
\end{tabular}

"Resolution could not be measured due to the coelution of the two peaks. 
simultaneously deals with numerous responses, taking their covariances into account. This provides an overview of the relationship between the responses and factors to determine the proper effect on all responses obtained within the statistical model. ${ }^{34}$

This provides an overview of the relationship between the responses and factors to determine the proper effect on all responses obtained within the statistical model.

The main effects of factors were identified for each response using the statistical model and are presented in Figure 3.

Higher amount of ACN and THF in the mobile phase A have negative effect on theoretical plates of RSV peak $(\mathrm{N})$, as presented in Figure 3. In addition, higher level of these two factors also has a negative effect on symmetry factor of RSV peak (T) and retention time of RSV peak (Rt). Higher amount of ACN and THF in the mobile phase A with the combination of higher column temperature also have negative effect on the resolution between RSV peak and RSV diastereoisomer (Res 1).

On the contrary, higher amount of ACN and THF in the mobile phase A have positive effect on resolution between impurity X peak and RSV lactone peak (Res 2), by improving the resolution between these two peaks. The most significant factors affecting the resolution between RSV lactone peak and RSV dehydro peak (Res 3 ) are buffer solution $\mathrm{pH}$ with negative effect and the amount of THF in the mobile phase A with positive effect.

Reducing the amount of $\mathrm{ACN}$ in the mobile phase $\mathrm{A}$ and reducing the buffer solution $\mathrm{pH}$ would lead to better responses of all measured resolutions.

All non-significant factors were excluded from the statistical model and the model was refitted.

Using MODDE integrated sweet spot analysis tool, the analytical operational design region was modeled. Appropriate suitability criteria were assigned to all the responses measured (see Table 3). Using the analysis tool the optimal chromatographic conditions were predicted (Figure 4).

The analytical method operational design region is presented for all four evaluated factors from the sweet spot diagram in Figure 4. The green area represents the part of the operational design region where all from statistical model calculated responses fulfil the criteria set for individual responses. This area is called the sweet spot. The black cross represents the optimal conditions as predicted by MODDE software tool. The outcome of the sweet spot analysis is in line with our preliminary conclusions obtained from the main effects plot (Figure 3). The sweet spot calculated by MODDE software tool is achieved by lowering buffer solution $\mathrm{pH}$, reducing the amount of $\mathrm{ACN}$ in the mobile phase $\mathrm{A}$ and raising the column temperature. No additional change was made to the amount of the THF in the mobile
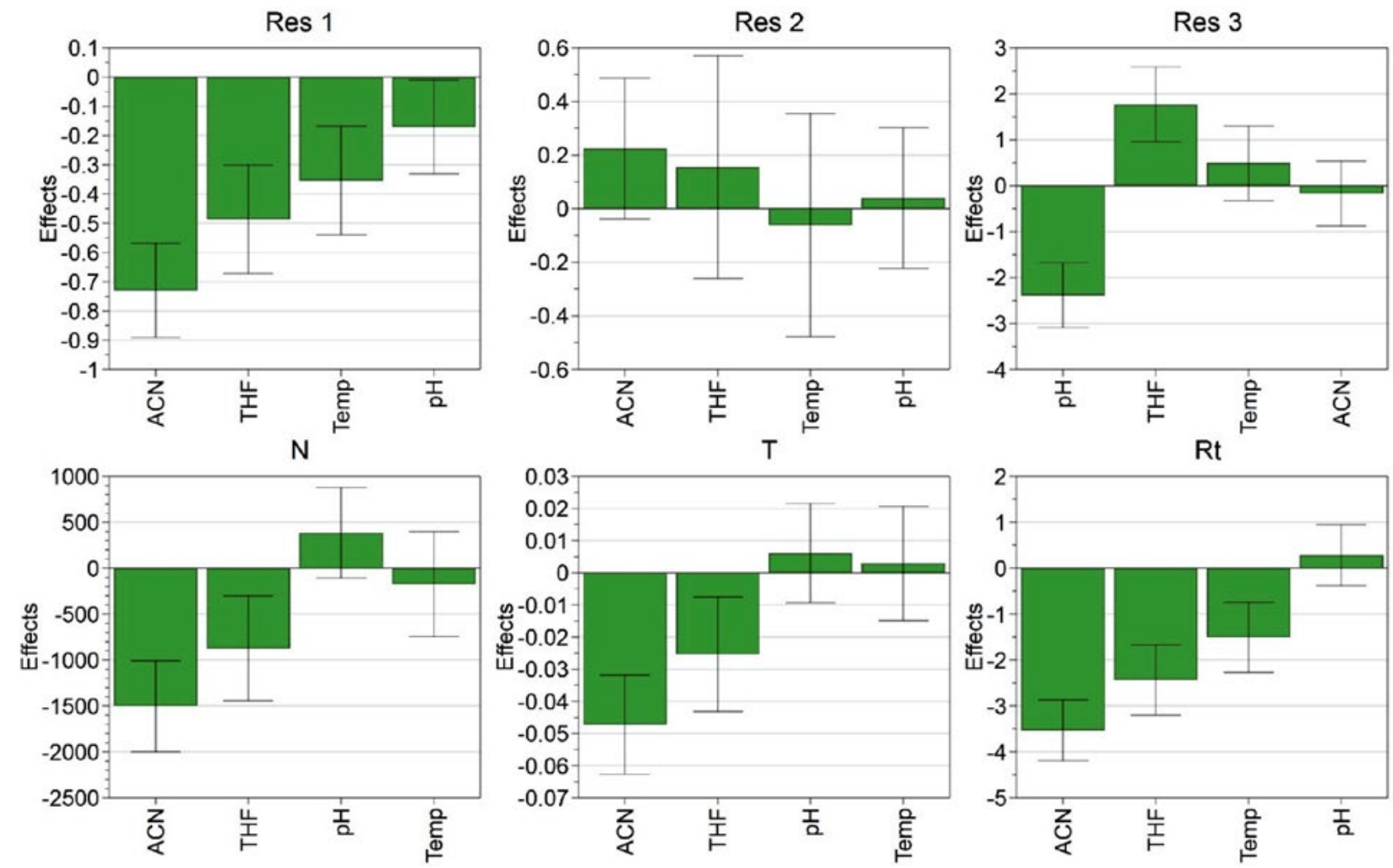

Figure 3. Main effects for all observed responses for UPLC method optimization for the determination of rosuvastatin and rosuvastatin degradation products. 

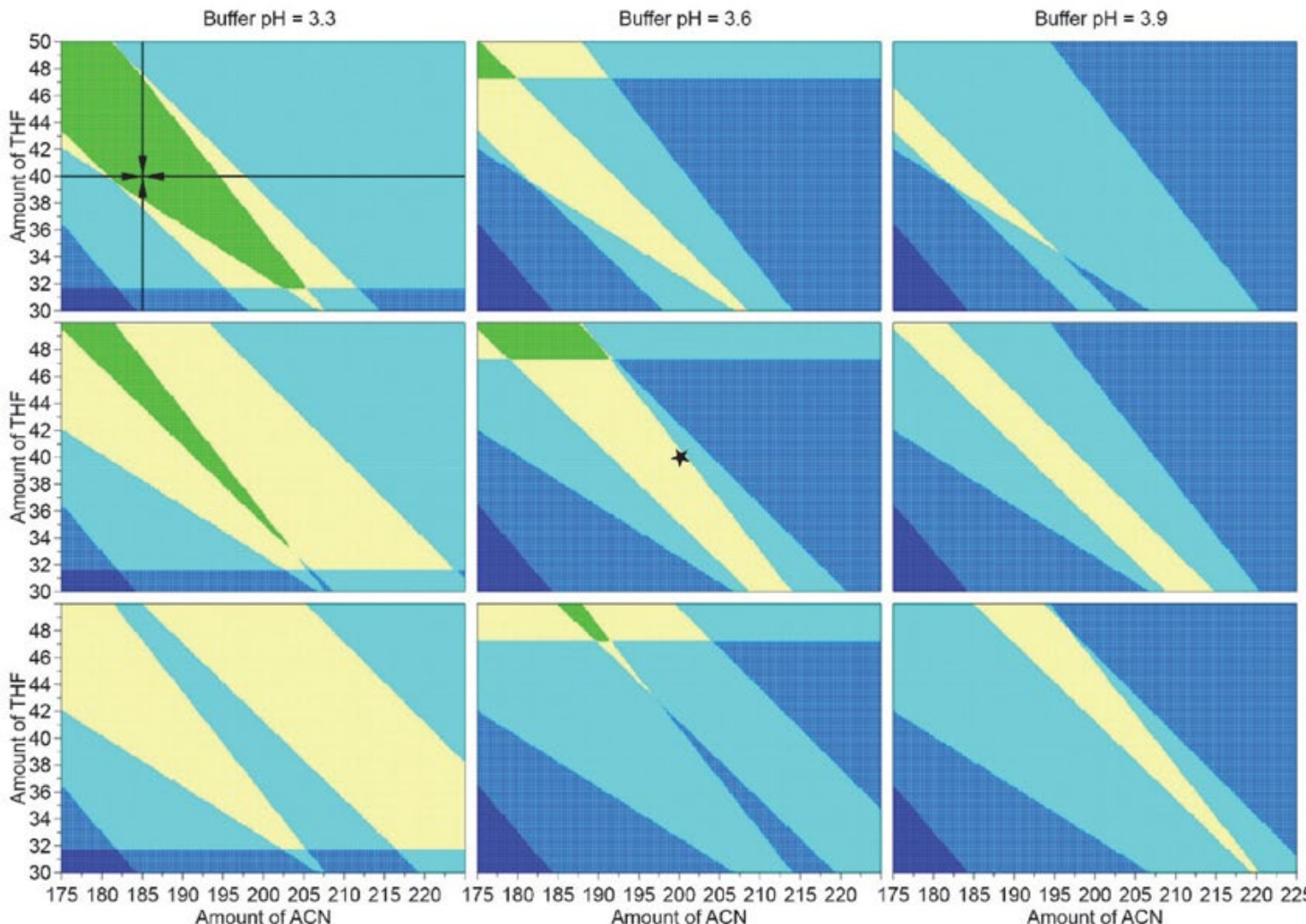

Sweet spot

Criteria met 5

C. Criteria met 4

II- Criteria met 3

Criteria met 1-2

兽

产
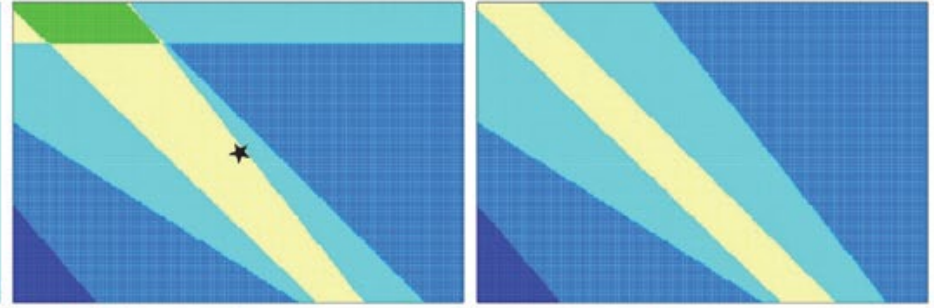

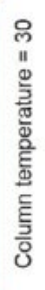
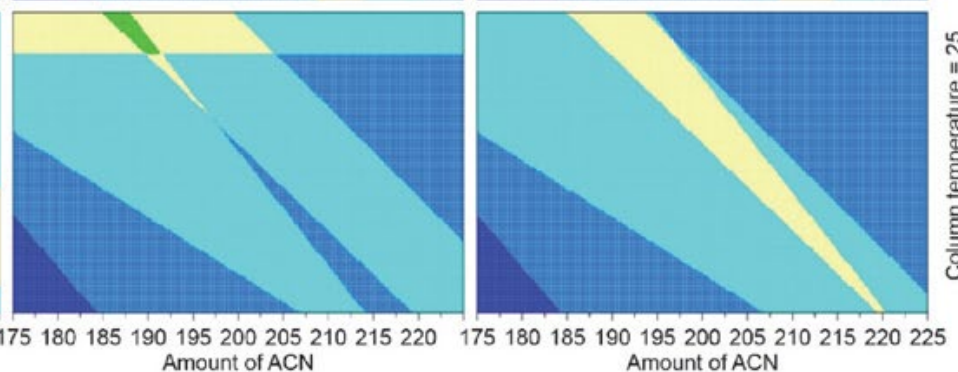

Figure 4. Sweet spot diagram for a PLS model of the analytical operational design region. Optimal chromatographic conditions proposed by MODDE are marked with a cross. The initial chromatographic conditions are marked with a star at the center of the figure.

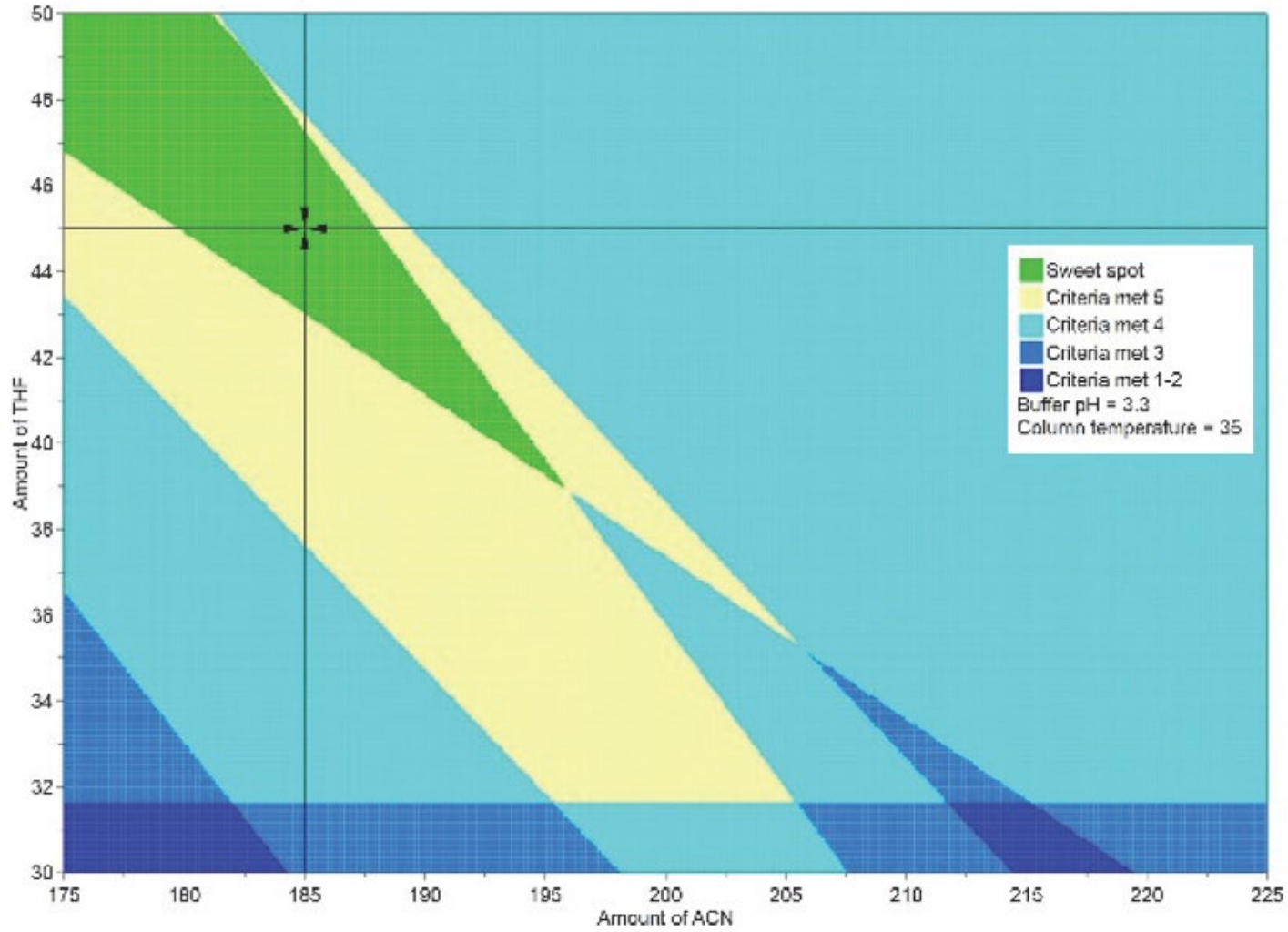

Figure 5. Sweet spot diagram for a PLS model of the analytical operational design region with weighted responses. 
phase. The chromatographic parameters of the initial sweet spot analysis are presented in Table 5 (initial sweet spot conditions) and in Figure 4 (marked with a star).

Using the suggested sweet spot chromatographic conditions, the degraded sample mixture was analyzed.

Chromatograms of degraded sample mixture (shown as a blue lines) and peak identification solution obtained with chromatographic conditions of the initial sweet spot and final sweet spot conditions (shown as black lines) are presented in Figure 6.

The resolution between impurity $\mathrm{X}$ peak and RSV lactone peak was not satisfactory when proposed initial sweet spot conditions were used while considerably better resolution between RSV and RSV diastereoisomer peak was achieved.

Since we had a statistical model for the analytical method operational design region no additional experiments were performed. MODDE sweet spot analysis was performed once again by weighing the importance of different responses measured. Resolution between RSV peak and RSV diastereoisomer peak (Res 1) and resolution between impurity X peak and RSV lactone peak (Res 2) were assigned with the highest weights, while the weights for all other responses were reduced. This way the sweet spot tool

Table 5. Initial chromatographic conditions compared to initial sweet spot conditions and final sweet spot conditions.

\begin{tabular}{lcccc}
\hline Factor name & Abbr. & $\begin{array}{c}\text { Initial } \\
\text { chromatographic } \\
\text { conditions }\end{array}$ & $\begin{array}{c}\text { Initial } \\
\text { sweet spot } \\
\text { conditions }\end{array}$ & $\begin{array}{c}\text { Final } \\
\text { sweet spot } \\
\text { conditions }\end{array}$ \\
\hline (f1) Buffer pH & $\mathrm{pH}$ & 3.6 & 3.3 & 3.3 \\
(f2) Amount of THF & $\mathrm{THF}$ & $40 \mathrm{~mL}$ & $40 \mathrm{~mL}$ & $45 \mathrm{~mL}$ \\
(f3) Amount of ACN & $\mathrm{ACN}$ & $200 \mathrm{~mL}$ & $185 \mathrm{~mL}$ & $185 \mathrm{~mL}$ \\
(f4) Column temperature & Temp & $30{ }^{\circ} \mathrm{C}$ & $35^{\circ} \mathrm{C}$ & $35^{\circ} \mathrm{C}$ \\
\hline
\end{tabular}
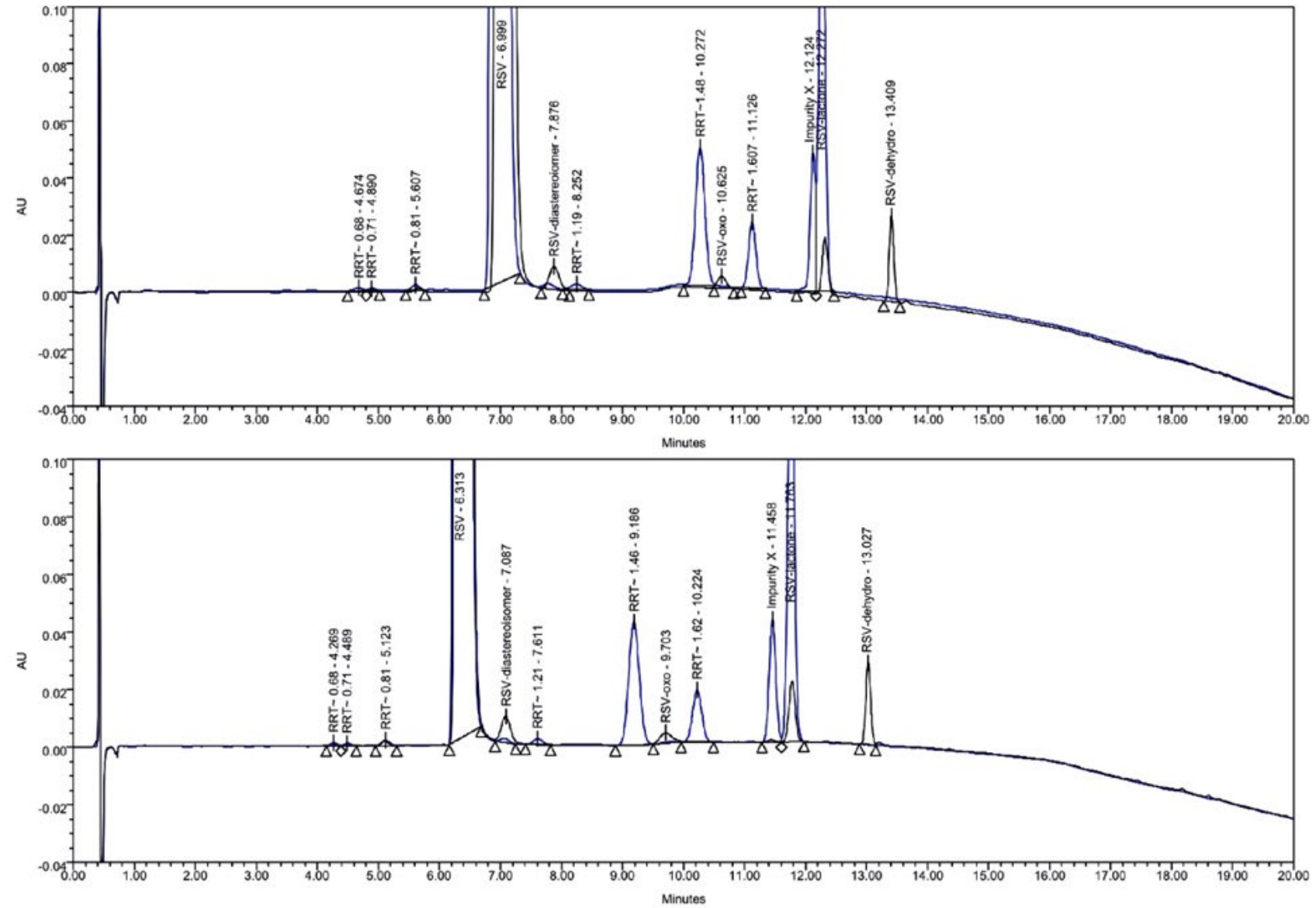

Figure 6. Chromatogram of the peak identification solution (black line) and degraded sample mixture (blue line) analyzed with initial sweet spot conditions (top) and final sweet spot conditions (bottom). 
was forced to find a spot with a satisfactory resolution between the critical pairs of impurities and not achieving the acceptance criteria for other responses. Additionally, the criteria for resolution between impurity X peak and RSV lactone peak (Res 2) was also tightened.

After running the sweet spot analysis again with the weighted responses, the new suggested sweet spot was calculated. The analytical method operational design region was modeled again and is presented in Figure 5. $\mathrm{pH}$ buffer solution value was fixed to 3.3 and column temperature to $35^{\circ} \mathrm{C}$. New optimal chromatographic conditions proposed by MODDE optimizer are marked with a cross.

The resolution between the unknown impurity $\mathrm{X}$ and RSV lactone could be improved with higher amounts of THF in the mobile phase. Suggested chromatographic parameters are presented in Table 5 (final sweet spot conditions).

The chromatogram obtained with the final sweet spot chromatographic conditions (Figure 6 bottom) shows significantly improved resolution between the impurity $\mathrm{X}$ peak and RSV lactone peak. The resolution between RSV peak and RSV diastereoisomer is significantly better than with the initial method. Despite all the method changes overall runtime of the analysis method was not prolonged.

\section{2. Analytical Method Validation}

The optimized analytical method was validated for determination of rosuvastatin and rosuvastatin degradation products in rosuvastatin tablets. Linearity, precision, accuracy, limit of detection and quantification were determined for main compound rosuvastatin and both specified degradation products RSV oxo and RSV lactone. The acceptance criteria for different validation parameters were set in line with ICH requirements. ${ }^{32}$

\section{2. 1. Linearity and Working Range}

The linearity of the method for determination of rosuvastatin was determined by using nine different standard solutions of rosuvastatin working standard. All solu- tions were prepared in three replicates. The covered concentration range was from $0.25 \mathrm{mg} / \mathrm{mL}$ to $0.75 \mathrm{mg} / \mathrm{mL}$ (50-150\% of target concentration. The linearity of rosuvastatin was determined using nine different solutions of rosuvastatin working standard prepared in three replicates for determination of related substances. The concentration range covered was from $0.15 \mu \mathrm{g} / \mathrm{mL}$ to $6.0 \mu \mathrm{g} / \mathrm{mL}$ (0.03- $1.2 \%)$. For rosuvastatin lactone and rosuvastatin oxo impurities, the linearity was determined using six different standard solutions prepared in three replicates. The concentration range covered for rosuvastatin lactone was $0.15 \mu \mathrm{g} / \mathrm{mL}$ to $6.0 \mu \mathrm{g} / \mathrm{mL}(0.03-1.2 \%)$ and for rosuvastatin oxo $0.25 \mu \mathrm{g} / \mathrm{mL}$ to $3.0 \mu \mathrm{g} / \mathrm{mL}(0.05-0.6 \%)$. The obtained linear regression results are presented in Table 6.

The response of all components was found to be linear in the tested concentration range. Good correlation coefficient $(>0.99)$ was obtained for all components.

\section{2. 2. Precision}

Repeatability of the analytical system for determination of rosuvastatin was check at the target concentration of rosuvastatin $(0.5 \mathrm{mg} / \mathrm{mL})$ by six replicate injections of the sample solution.

Repeatability was also validated for known rosuvastatin impurities RSV lactone and RSV oxo. The results of individual impurities are expressed as \% (percentage) of RSV lactone and \% of RSV oxo. The obtained results and RSD of the measurements are presented in Table 7.

Intermediate precision was performed by injecting six sample solution replicates. The study was done by different analyst that performed the analysis on different days, different chromatographic systems and different UPLC columns. All together six different variations were performed. Assay of rosuvastatin, \% of RSV lactone and \% of RSV oxo were measured. The results are presented in Table 7.

The results in Table 7 demonstrate good precision of the method for assay determination, RSD value $<1.0 \%$. The precision for individual impurities was found to be acceptable as the criteria for RSD ( $\mathrm{n}=6$ or 36$)$ of the impurities measured at this level was set to $<20 \%$.

Table 6. Average linear regression data for RSV, RSV lactone and RSV oxo obtained for optimized UPLC method.

\begin{tabular}{|c|c|c|c|c|c|}
\hline Component & $\begin{array}{c}\text { Target and concentration } \\
\text { range } \\
{[\mu \mathrm{g} / \mathrm{mL}]}\end{array}$ & Slope & $\begin{array}{l}\text { Intercept } \\
\text { bias in \% }\end{array}$ & Intercept & $\mathbf{R}^{2}$ \\
\hline RSV for assay determination & $\begin{array}{c}500 \\
250-750\end{array}$ & 2929137 & 6892266 & 0.47 & 0.9998 \\
\hline RSV for degradation products & $\begin{array}{c}1.3 \\
0.15-6.0\end{array}$ & 7662070 & 999981 & 5.05 & 0.9981 \\
\hline RSV lactone & $\begin{array}{c}2.9 \\
0.15-5.9\end{array}$ & 8030538 & -14466 & -0.06 & 0.9996 \\
\hline RSV oxo & $\begin{array}{c}2.5 \\
0.25-3.0\end{array}$ & 5354275 & -51492 & -0.71 & 0.9994 \\
\hline
\end{tabular}


Table 7. Repeatability and intermediate precision results for RSV, RSVlactone and RSV oxo.

\begin{tabular}{|c|c|c|c|c|}
\hline \multirow[t]{2}{*}{ Component } & \multicolumn{2}{|c|}{ Precision } & \multicolumn{2}{|c|}{ Intermediate precision } \\
\hline & $\%$ content $^{1}$ & $\% \mathrm{RSD}^{2}$ & $\%$ content $^{3}$ & $\% \mathrm{RSD}^{4}$ \\
\hline RSV for assay determination & 99.61 & 0.96 & 98.89 & 0.71 \\
\hline RSV lactone & 0.111 & 2.23 & 0.105 & 10.72 \\
\hline RSV oxo & 0.091 & 4.59 & 0.080 & 12.30 \\
\hline
\end{tabular}

${ }^{1}$ average of 6 determinations; ${ }^{2}$ determined on 6 measurements; ${ }^{3}$ average of 36 determinations; ${ }^{4}$ determined on 36 measurements

\section{2. 3. Accuracy}

The accuracy of the proposed analytical method was checked at three concentration levels. For rosuvastatin determination the range was from $70 \%-130 \%$ of the target assay determination concentration. For the determination of degradation products, the accuracy for rosuvastatin was checked in range $0.03 \%(0.15 \mu \mathrm{g} / \mathrm{mL})-0.24 \%(1.2 \mu \mathrm{g} / \mathrm{mL})$, for RSV lactone in range $0.03 \%(0.15 \mu \mathrm{g} / \mathrm{mL})-1.2 \%(6.0$ $\mu \mathrm{g} / \mathrm{mL})$ and for RSV oxo in range $0.05 \%(0.25 \mu \mathrm{g} / \mathrm{mL})-0.6$ $\%(3.0 \mu \mathrm{g} / \mathrm{mL})$.

All samples were prepared by spiking the appropriate amount of a component into a placebo solution. Spiked samples were prepared in three replicates and analyzed by the proposed optimized analytical method. The recovery factor was calculated and obtained results are presented in Table 8.

As presented in Table 8 the recovery for the determination of rosuvastatin is acceptable. Individual recovery values were within $\leq 100 \pm 3 \%$ and the $\mathrm{RSD}_{(\mathrm{n}=3)}$ of the obtained recovery values was below $2 \%$, demonstrating good accuracy of the method for determination of rosuvastatin in rosuvastatin drug products.

The accuracy for degradation products determination was also satisfactory for all components. The calculated recovery was within $80-120 \%$ for all components and the RS$\mathrm{D}_{(\mathrm{n}=3)}$ of the obtained recovery values was below $20 \%$.

\section{2. 4. Limit of Detection}

The detection limits were determined on the basis of signal-to-noise $(\mathrm{S} / \mathrm{N})$ ratio $\geq 3: 1$ according to $\mathrm{ICH}$ guidelines. The signal-to-noise values and calculated LOD concentrations are presented in Table 9.

The calculated obtained LOD concentration are $0.009 \mu \mathrm{g} / \mathrm{mL}$ for rosuvastatin, $0.009 \mu \mathrm{g} / \mathrm{mL}$ for RSV lac-

Table 8. Results of recovery experiments at five concentration levels of RSV, RSV lactone and RSV oxo, obtained with optimized UPLC method.

\begin{tabular}{|c|c|c|c|c|}
\hline Component & & Level 1 & Level 2 & Level 3 \\
\hline \multirow{3}{*}{$\begin{array}{l}\text { RSV for assay } \\
\text { determination }\end{array}$} & Concentration range & $70 \%(350 \mu \mathrm{g} / \mathrm{mL})$ & $100 \%(500 \mu \mathrm{g} / \mathrm{mL})$ & $130 \%(650 \mu \mathrm{g} / \mathrm{mL})$ \\
\hline & Mean recovery ${ }^{1}$ & 101.31 & 101.18 & 101.17 \\
\hline & $\% \mathrm{RSD}^{2}$ & 0.16 & 0.29 & 0.25 \\
\hline \multirow{3}{*}{$\begin{array}{l}\text { RSV for degradation } \\
\text { products } \\
\text { determination }\end{array}$} & Concentration range & $0.03 \%(0.15 \mu \mathrm{g} / \mathrm{mL})$ & $0.20 \%(1.0 \mu \mathrm{g} / \mathrm{mL})$ & $0.24 \%(1.2 \mu \mathrm{g} / \mathrm{mL})$ \\
\hline & Mean recovery ${ }^{1}$ & 102.56 & 101.47 & 103.88 \\
\hline & $\% \mathrm{RSD}^{2}$ & 9.82 & 4.07 & 3.25 \\
\hline \multirow{3}{*}{ RSV lactone } & Concentration range & $0.03 \%(0.15 \mu \mathrm{g} / \mathrm{mL})$ & $1.0 \%(5.0 \mu \mathrm{g} / \mathrm{mL})$ & $1.2 \%(6.0 \mu \mathrm{g} / \mathrm{mL})$ \\
\hline & Mean recovery ${ }^{1}$ & 110.14 & 105.49 & 104.84 \\
\hline & $\% \mathrm{RSD}^{2}$ & 4.63 & 0.54 & 0.75 \\
\hline \multirow{3}{*}{ RSV oxo } & Concentration range & $0.05 \%(0.25 \mu \mathrm{g} / \mathrm{mL})$ & $0.5 \%(2.5 \mu \mathrm{g} / \mathrm{mL})$ & $0.6 \%(3.0 \mu \mathrm{g} / \mathrm{mL})$ \\
\hline & Mean recovery ${ }^{1}$ & 108.97 & 99.76 & 100.01 \\
\hline & $\% \mathrm{RSD}^{2}$ & 6.79 & 0.38 & 0.51 \\
\hline
\end{tabular}

${ }^{1}$ average of 3 determinations; ${ }^{2}$ determined on 3 measurements

Table 9. Results of signal-to-noise values and LOD for RSV, RSV lactone and RSV oxo impurities obtained with optimized UPLC method.

\begin{tabular}{lcccc}
\hline Component & $\begin{array}{c}\text { Concentration } \\
\text { \% of RSV }\end{array}$ & $\begin{array}{c}\text { Concentration } \\
\boldsymbol{\mu g} / \mathbf{m L}\end{array}$ & $\begin{array}{c}\text { Average S/N ratio } \\
(\mathbf{n}=\mathbf{6})\end{array}$ & $\begin{array}{c}\text { LOD } \\
\boldsymbol{\mu g} / \mathbf{m L}\end{array}$ \\
\hline RSV & 0.01 & 0.05 & 16.5 & 0.009 \\
RSV lactone & 0.01 & 0.05 & 15.9 & 0.009 \\
RSV oxo & 0.02 & 0.1 & 10.6 & 0.028 \\
\hline
\end{tabular}


Table 10. Results of signal-to-noise values and LOQ for RSV, RSV lactone and RSV oxo impurities obtained with optimized UPLC method.

\begin{tabular}{lcccc}
\hline Component & $\begin{array}{c}\text { Concentration } \\
\text { \% of RSV }\end{array}$ & $\begin{array}{c}\text { Concentration } \\
\boldsymbol{\mu g} / \mathbf{m L}\end{array}$ & $\begin{array}{c}\text { Average } \mathbf{S} / \mathbf{N} \text { ratio } \\
(\mathbf{n}=\mathbf{6})\end{array}$ & $\begin{array}{c}\text { LOQ } \\
\boldsymbol{\mu g} / \mathbf{m L}\end{array}$ \\
\hline RSV & 0.03 & 0.15 & 51.8 & 0.029 \\
RSV lactone & 0.03 & 0.15 & 48.8 & 0.031 \\
RSV oxo & 0.05 & 0.25 & 25.9 & 0.097 \\
\hline
\end{tabular}

tone and $0.028 \mu \mathrm{g} / \mathrm{mL}$ for RSV oxo impurity. The determined $\mathrm{S} / \mathrm{N}$ ratios are higher than required 3 , however lower quantification limits are not needed since the reporting limit for impurities is $0.05 \%$ with respect to the concentration of rosuvastatin in the sample.

\section{2. 5. Limit of Quantification}

The quantitation limits were determined on the basis of signal-to-noise $(\mathrm{S} / \mathrm{N})$ ratio $\geq 10: 1$ according to $\mathrm{ICH}$ guidelines. The signal-to-noise values and calculated LOQ concentrations are presented in Table 10.

The calculated obtained LOQ concentration are $0.029 \mu \mathrm{g} / \mathrm{mL}$ for rosuvastatin, $0.031 \mu \mathrm{g} / \mathrm{mL}$ for RSV lactone and $0.097 \mu \mathrm{g} / \mathrm{mL}$ for RSV oxo impurity. The determined $\mathrm{S} / \mathrm{N}$ ratios are higher than required 10 , but lower quantification limits are not needed as the reporting limit for impurities is $0.05 \%$ with respect to the concentration of rosuvastatin in the sample.

\section{Conclusions}

The optimization of a new analytical method capable of simultaneous determination of rosuvastatin assay and its degradation products in rosuvastatin drug products was performed with a single fractional factorial experimental design. Only 11 experiments were needed for the optimization, while at least 16 experiments would be needed to cover the same analytical method operational region of the first optimization step with a traditional one factor at time (OFAT) approach.

During the optimization, it was demonstrated that it is necessary to do the optimization of analytical methods with a sample that contains all possible degradation products. The degradation of the sample in this article was performed by artificial sun-light and acid hydrolysis as this was proven to be the most stability indicating condition for rosuvastatin.

It was shown that with the appropriate statistical model of the analytical method operational region one can also do the optimization with no additional experiments, if the outcome of the first trial is not satisfactory. The responses can be weighted and the sweet-spot analysis run again on the same set of experiments.

The final analytical method optimized with $\mathrm{QbD}$ approach was validated according to ICHQ2R1 guideline. ${ }^{32}$ The method was found to be linear, accurate and precise for both rosuvastatin assay determination and determination of rosuvastatin degradation products. The validated method was successfully applied for rosuvastatin drug products.

The final optimized method is stability indicating and is capable to detect all changes in the rosuvastatin product(s) that are stored at different storage and stress stability conditions. It enables to determine the content of rosuvastatin and its degradation products in a single injection run. This optimization reflects in saving of time and resources since one stability study includes hundreds of samples tested during the product's shelf life.

\section{References}

1. R. P. Shah, A. Sahu, S. Singh, Anal Bioanal Chem 2013, 405, 3215-3231. DOI:10.1007/s00216-013-6760-1

2. A. G. Olsson, F. McTaggart, A. Raza, Cardiovasc Drug Rev 2002, 20, 303-328. DOI:10.1111/j.1527-3466.2002.tb00099.x

3. K. C. Ferdinand, Expert opinion on pharmacotherapy 2005, 6, 1897-1910. DOI:10.1517/14656566.6.11.1897

4. F. G. Vogt, A. S. Kord, J. Pharm. Sci. 2011, 100, 797-812. DOI:10.1002/jps.22325

5. J. Ermer, P. J. Borman, J. Carolan, P. Faulkner, C. Finkler, O. Grosche, M. Hanna-Brown, J. Hoffmann, I. Gill, A. Lenhart, P. W. Nethercote, A. Rignall, T. Sokoliess, G. Wegener, M. Pohl, Pharmind 2010, 72, 256-264.

6. P. Borman, P. Nethercote, M. Chatfield, D. Thompson, K. Truman, Pharm. Technol. 2007, 31, 142-152.

7. ICH Guideline: Pharmaceutical Development Q8(R2), CHMP/ ICH/167068/04.

8. Pharmaceutical cGMPs for the 21st Century - A Risk-Based Approach, U.S. Food and Drug Administration (FDA).

9. S. Bohanec, T. Rozman Peterka, P. Blažič, R. Jurečič, J. Grmaš, A. Krivec, J. Zakrajšek, Acta Chim. Slov. 2010, 57, 895-903.

10. P. Petelin, M. Homar, A. Bajc, J. Kerč, S. Bohanec, Acta Chim. Slov. 2012, 59, 156-162.

11. M. Schweitzer, M. Pohl, M. Hanna-Brown, P. Nethercote, P. Borman, G. Hansen, K. Smith, J. Larew, Pharm. Technol. 2010, 34, 52-59.

12. P. Borman, J. Roberts, C. Jones, M. Hanna-Brown, R. Szucs, S. Bale, Sep. Sci. 2010, 2, 2-8.

13. T. W. Graul, K. L. Barnett, S. J. Bale, I. Gill, M. Hanna-Brown, in: D. J. am Ende (Ed.): Chemical Engineering in the Pharmaceutical Industry: R\&D to Manufacturing, Wiley, Hoboken, NJ, US, 2011, pp. 545-562. 
14. M. Moder, S. Bohanec, J. Zupan, Acta Chim. Slov. 1997, 44, 181-196.

15. S. Karmarkar, R. Garber, Y. Genchanok, S. George, X. Yang, R. Hammond, J. Chromatogr. Sci. 2011, 49, 439-446. DOI:10.1093/chrsci/49.6.439

16. D. Awotwe-Otoo, C. Agarabi, P. J. Faustino, M. J. Habib, S. Lee, M. A. Khan, R. B. Shah, J. Pharm. Biomed. Anal. 2012, 62, 61-67. DOI:10.1016/j.jpba.2012.01.002

17. M. Hanna-Brown, P. Borman, S. Bale, R. Szucs, J. Roberts, C. Jones, Sep. Sci. 2010, 2, 12-20.

18. L. Zhou, J. M. Socha, F. G. Vogt, S. Chen, A. S. Kord, Am. Pharm. Rev. 2010, 74-84.

19. S. J. Varghese, T. K. Ravi, J AOAC Int 2010, 93, 1222-1227.

20. S. Ashour, S. Omar, Int J Biomed Sci 2011, 7, 283-288.

21. S. K. Banerjee, N. M. Vasava, Bull. Pharm. Res 2013, 3, 29-33.

22. A. K. Gajjar, V. D. Shah, Eurasian journal of analytical chemistry 2010, 5, 265-283.

23. M. A. Mukthinuthalapati, V. Bukkapatnam, S. P. Bandaru, Adv Pharm Bull 2014, 4, 405-411.

24. Z. M. Turabi, O. h. A. Khatatbeh, International Journal of Pharmaceutical Sciences and Drug Research 2014, 6, 154-159.
25. G. V. R. Reddy, B. V. Reddy, S. W. Haque, H. D. Gautam, P. Kumar, A. P. Kumar, J. H. Park, Química Nova 2011, 34, 250255. DOI:10.1590/S0100-40422011000200015

26. T. N. Mehta, A. K. Patel, G. M. Kulkarni, G. Suubbaiah, J AOAC Int 2005, 88, 1142-1147.

27. S. Palvai, S. C. Seelam, K. Dhanalakshmi, N. Reddy, International Journal of Pharmacy \& Therapeutics 2013, 4, 182-187.

28. Y. Shah, Z. Iqbal, L. Ahmad, A. Khan, M. I. Khan, S. Nazir, F. Nasir, J Chromatogr B Analyt Technol Biomed Life Sci 2011, 879, 557-563. DOI:10.1016/j.jchromb.2011.01.004

29. S. J. Varghese, T. K. Ravi, J AOAC Int 2013, 96, 307-312. DOI:10.5740/jaoacint.11-117

30. R. Maheswaran, Pharm. Technol. 2012, 36, 73-80.

31. ICH Guideline: Stability Testing of New Drug Substances and Products Q1A(R2), CPMP/ICH/2736/99.

32. ICH Guideline: Validation of Analytical Procedures: Text and Methodology Q2(R1), CPMP/ICH/381/95.

33. ICH Guideline: Stability Testing: Photostability Testing of New Drug Substances and Products Q1B, CPMP/ICH/279/95.

34. L. Eriksson, E. Johansson, N. Kettaneh-Wold, C. Wikstrom, S. Wold: Design of Experiments - Principles and Applications, Umetrics AB, Umea, Sweden, 3rd ed., 459, 2008.

\section{Povzetek}

$\mathrm{Z}$ uporabo delnega faktorskega načrta smo ovrednotili vpliv štirih kromatografskih parametrov in izvedli optimizacijo visoko ločljivostne tekočinske kromatografske metode za hkratno določitev rosuvastatina in njegovih razkrojnih produktov. Nova optimizirana metoda omogoča natančno določitev vsebnosti rosuvastatina in vseh razkrojnih produktov rosuvastatina $\mathrm{v}$ farmacevtskih pripravkih, ki vsebujejo rosuvastatin.

S pomočjo programa Umetrics MODDE smo izdelali model, ki opisuje delovno območje analitske metode, in napovedali optimalne pogoje kromatografske ločbe. Rezultati statističnega modela so pokazali, da so najpomembnejši parametri, ki zagotavljajo najboljšo ločbo med rosuvastatinom in njegovimi nečistotami, $\mathrm{pH}$ puferne raztopine in količina ACN ter THF v mobilni fazi.

Analitsko metodo za določitev rosuvastatina in njegovih razkrojnih produktov, optimizirano s pomočjo QbD pristopa, smo validirali, pri čemer smo ovrednotili njeno linearnost, točnost in natančnost. Za dve znani specificirani nečistoti smo določili mejo določitve in mejo zaznave.

Uporaba programa za statistično načrtovanje poskusov nam je omogočila izvedbo optimizacije le $\mathrm{z}$ utežitvijo spremljanih odzivov in ponovnim vrednotenjem delovnega območja analitske metode, brez izvedbe dodatnih poskusov. $\mathrm{S}$ statističnim načrtovanjem poskusov smo dobili kar največ informacij o delovnem območju analitske metode $\mathrm{z}$ najmanjšim možnim številom izvedenih poskusov. S takšnim pristopom se zmanjšajo tudi stroški razvoja metode, saj nam statistično načrtovanje poskusov omogoča hkratno obravnavo različnih parametrov in njihovih medsebojnih interakcij. 